\title{
Glorifying War in Iraqi Children's Short Stories 1980s
}

\author{
Taymaa H. Kheirbek ${ }^{1}$ \\ ${ }^{1}$ English Department, College of Education and Languages, Charmo University, Kurdistan Region, Iraq
}

\begin{abstract}
Throughout history, literature has always played a key role in forming societies' cultural heritage. Children Literature, in specific, is highly important since it helps the young readers to develop love and passion for reading which will eventually improve their emotional intelligence and creativity. It also nurtures significant social skills that enable the readers to have more positive attitudes about their lives. Nevertheless, children's literature can turn into a tool to control children and brainwash them. Studying Iraqi children's short stories during the 1980s shows how children are enculturated and treated as rich soil to sow the seeds of violence. In this paper, a selected number of short stories that were written during Iran-Iraq war are studied. It examines how these texts are engaged in literature of propaganda. It also focuses on the tools that are used to covey certain ideologies. The normalization, historicization, and mythologization of war are proved to be highly influential methods. Propagandistic and militaristic subjects and illustrations are also employed to convey implied ideological messages. The soldiers' suffering is hidden while their death is celebrated. Instead of portraying the ferocity of war to remind young readers of its inhumane side, violence is encouraged, and the idea of peace is trivialized and rejected.
\end{abstract}

KEY WORDS: Children's Literature, Iraq, Normalization of War, Short Stories, War

\section{INTRODUCTION:}

Iraqi children's literature during the 1980s aimed at producing a particular kind of texts that contained implied ideological perspectives through glorifying IraqIran war. Children, at that time, were constantly exposed to stories celebrating battlefields and martyrhood. The political and ideological constitutions in Saddam Hussein's regime influenced children from a young age and shaped their childhood. There were some systematic campaigns that tried to achieve the subjectification of children by the governing systems, media, and children's literature. The governing regime intentionally involved children in the war by presenting them with special texts which not only glorify war, but also justify it. The paper examines a selected number of short stories

Koya University Journal of Humanities and Social Sciences (KUJHSS), Volume 4, Issue 1, 2021.

Received 01 Jan 2021; Accepted 01 Apr 2021, Regular research paper: Published 30 Jun 2021

Corresponding author's e-mail: taymahusseinali@gmail.com Copyright (C2021. Taymaa H. Kheirbek, this is an open access article distributed under the Creative Commons Attribution License. that were published during the 1980s. The analyzed stories focus on the tools that are used to present war in a glorified and celebrated way. Writers primarily used the normalization of war method, in order to make it closer to children's everyday life. In addition to this, they also used historicized war stories to have a more profound impact on children. This has been achieved by praising violence and using propagandistic and militaristic subjects and illustrations.

War in children's literature has always been a controversial issue for critics and readers alike. The themes of war and peace are present in such texts as part of the process to attract the children. As they communicate the idea of peace, stories also shed the light on how conflict is part of life. Elizabeth Goodenough (2000) in her article 'Violence in children's literature: Introduction' states that stories sooth young readers in trauma by gently leading them to use their imagination to mediate, repair, and preside over the invention of novel meanings in a new modern world. Such stories also teach them how to deal with conflicts. Although happy endings are considered part of the plot in children's literature, this tradition started to change during 1960s. Modern writers, through realistic fiction, 
tend to address many topics that tackle tough issues in which happy endings are not a must. Despite severe criticism, such texts continued even when they are rejected in the 21st century. Some critics consider this type of literature motivating and encouraging to violence, while others perceive it as emphasizing the importance of peace and bring it under spot light (Salwi 1998). Giblin (1995) suggests that peace should not be portrayed as suddenly won, but a process of understanding the reasons and the factors of war. The end of the war should not be depicted as 'the happy ever after', because this is nothing but trivializing the atrocious reality of war. As a result, dealing with war as a frequent topic in children's literature has witnessed considerable development. While it was about the conflict between good and evil, it comes to be simply a matter of presenting it without any glorification.

Ideology can be defined as a system of beliefs which a society usually shares and uses to present a sounder understanding of the world and which consequently inherited in the texts produced by that society. Exploring the ideological implications, the way in which the child reader is constructed by the text he/she reads, is a keyword in this paper. Through this, one can fully comprehend how these texts played a significant role in not only shaping the children's future mentally, but also influencing generations.

The construction of young readers remains a significant issue in literary criticism. In 1984, Jacqluine Rose researched this essential point in relation to children's fiction. Her argument lies in the fact that there are some elements like textual devices, characterization, and assumptions of value position that may be so critical in constructing children, both as characters and readers. Children are simply regarded as beings with a privileged perception, unattained by culture. Reading these texts raises a key question if there is any ideology behind them.

In general, critics agree that ideologies exist in texts produced for children. The social assumptions about gender, race, and class started to influence the production and reception of the children's literature (McCllum and Stephens 2010, p.360). Among the first studies conducted on this was Bob Dixon's 'Catching them young' in which ideas, attitudes, and opinions that authors tend to convey in their works are examined (1977). John Stephens (1992) also states that 'Ideology is formulated in and by language, meanings within language are socially determined, and narratives are constructed out of language. These texts typically have two functions. The first presents a social function to define and preserve the community's values. This function assumes that the authors and implied readers share a common understanding value. The second focuses on the cognitive function which usually supplies a meaningful set of the social attitudes and relationships which construct narrative plots (McCllum and Stephens 2010, p.360).

Prevailing ideologies depend on the consequences of social practices based on them being acceptable or not. For example, both racism and antiracism represent an ideology. Therefore, ideologies can be seen as a tool to establish or maintain social dominance, as well as to organize an opposition. The impossibility of ideology can be applied to all texts. Critics believe that books which seem to be ideology-free, in fact, are not. These books are merely closer to the reader's unconscious assumptions which make identifying them a difficult task. It usually requires a very careful reading of the texts' language and narrative discourse. In order to be able to distinguish any implied ideological structures in text, it is highly recommended to carefully analyze it linguistically and semantically, since ideology is embedded into linguistic and visual semiotic systems. These systems include sentence syntax, lexical selection, topicalization or implicitness, and conversational dynamics. It is significant to mention that ideology exists in all three constitutes of a literary work: the discourse, story, and significance. By discourse, it means the linguistic structure. The story refers to characters and the actions they involve in. Finally, the significance deals with the organization of social attitudes and values (ibid).

In order to understand the influence of such texts on children, it is highly recommended to distinguish the key concepts of subject positions that are implied in them. Andrea Schewenke Wyile (1999, p.195) distinguishes three types of narration in children's literature which expressively show the subject position concept. She argues that if the time of the narration is close to or in coincidence with events narrated, and the narrator is a focalizer, readers usually identify with the narrator-protagonist. Therefore, readers will align with the subject position and the social attitudes, presented by the protagonist. This first category is called immediate-engaging first- person narration. The second type is an immediate-engaging third-person narration which is considered heavily character focalized and leaves the same influence on readers as the first one. The third one is distant-engaging narration which, as Wyile concludes, is not prevalent in children's literature. Interestingly, texts may include one or all three types which add a lot to the concept of subject position.

Using war as a theme in children's literature is highly controversial. Some critics assume that war is not a suitable theme for children's literature since it is 
considered crossing the boundaries of literature. The main argument is that it ignores one of the most important concepts of children's literature which is hope (Fox and Hunt, 2004, p.500). Hope is crushed under the heaviness of death as a recurrent motif in war stories. Since these two cannot coincide, it is very difficult to coexist. When literature cannot empower children, then its main function is idle. Eric Kimmel, who is one of those critics who highly reject the idea of including war in children's books, wonders whether mass murder is a subject for a children's novel (Harrison 1987, p.70).

Equally, other critics believe that children should not be over-protected. Instead, they should be offered realistic stories. Edward Ardizzone avers, "I think we are inclined, in a child's reading, to shelter him too much from the harder facts of life. Sorrow, failure, poverty, and possibly even death, if handled poetically, can surely all be introduced without hurt...If no hint of the hard world comes into these books, I am not sure that we are playing fair " (1980, p. 293). Barbara Harrison, a prominent writer about the Jewish Holocaust, also states that "war is an ever-present reality of vast numbers of children; we who can choose to keep our children ignorant are a minority" (1987, p.87). Literature can arouse compassion. Therefore, children learn from such stories how to empathize with others. Reading about the suffering of people during war can be a message about the atrocities of war. Consequently, they will be educated about peace as an essential concept in humans' life. Masha Rudman, in her book 'Children's Literature', states that the use of war as a theme in literature is mainly about how people behave with each other and how communities are moving forward and built in times of peace, while they are completely destroyed in times of war. She also suggests certain criteria in order to write about war in children's literature, such as the cause of war should be described simplistically, battles should not be glorified, there should be a clear distinction between including facts and opinions, the realities of war are not supposed to be trivialized, peace should not be depicted as easily and suddenly won, and finally, it is important to mention that the end of war does not indicate the end of problems (1995, pp369-71).

\section{IRAQI CHILDREN'S SHORT STORIES DURING 1980s}

The 1980s witnessed the longest conventional war in the 20th century; the Iran-Iraq war. Its beginning is controversial since Iran claims that Iraq invaded the western borders on the 22nd of September 1980, while Iraq considered it a reply to Iran's shelling some border posts on the 4 th of September 1980. The war lasted for 8 years, ending by 1988 cease-fire. The number of causalities ranges from $1,000,000$ to twice that number. It is estimated that at least 500,000 were killed on both sides (Augustyn 2020).

Iraqi children's literature during the 1980s seemed to be inseparable from the war itself. War had become normalized through being a current theme in children's stories, fueling young readers' imaginations with constant militaristic motifs. Part of the process of propaganda is mythologizing war. The Iraqi regime, at that time, followed a systemized process in order to involve all sectors in building the war myth. Children's literature was not an exception. Dr. Shafiq Mahdi, a well-known Iraqi author who was the secretory editor of Majalty and Almizmar, confirms that writers working in Children's Culture House were obliged to include stories with war and militaristic themes. As a result, children's magazines and books were filled with plots and illustrations glorifying the war (T. Kheirbek 2020, personal communication, 2 November). The real reasons behind the war were never discussed, and its hideous face was hidden. There were constant attempts to present war as a test for citizens' love of their country.

Every war has its own form of propaganda. It has been intentionally used in Iraqi children's short stories as an effective tool to convey rather misleading messages. Since the war was unjustified, people (including children) needed to be convinced about its necessity. The information industry served a lot to celebrate patriotic indoctrination. It was a process of numbing public opinion through the normalization of war. The political propaganda depicted the enemy in a demonized way which led to glorify the idea of selfsacrifice for nationalistic reasons. Therefore, patriotism was lavishly praised and death was trivialized. The main aim was to feed the minds of generations of children with lies about the noble cause of war.

The mobilization for war was performed on various levels and took several aspects. Children's literature was not an exception. Writers, under the pressure of the Iraqi regime at that time, established a systematic process of involving children in war. Through literature, they were calling for celebrating a national identity through describing heroic actions (of the past and the present), exalting the role of the army in defending the country, and emphasizing the notions of sacrifice and heroism. These concepts can be easily tracked in most of the short stories that were written during the war. Part of the mobilization to the war was to identify children with soldiers by reinforcing the national ideology. Consequently, writers tended to create stereotypes of war characters who instantly became role models.

Childhood and the language of children's literature were highly exploited at that time since children were regarded as seeds that will bear any ideological concepts 
they read. Therefore, the propagandists formed it in a way to convey their ideological messages to young readers who will instinctively accept. Children were also seen as individuals who were constantly in need of political nurturing. As a result, heavy use of politically charged texts was common during Iran-Iraq war. The aim was to powerfully build a public mentality that not only accepts war but also justifies it.

Majalaty (My Magazine), is considered one of the oldest children's magazines, starting in 1969 until now. For decades, it offered a broad range of stories and poems that formed the memory of generations. Undoubtedly, the subjects presented differed according to the political circumstances that the country witnessed. During the 1970s, Iraq saw flourishment in all sectors of life. Therefore, the key topics presented in Majalaty were adequately reflecting this economic and social development. In September 1980, the magazine initiated a new era, in which war stories were prevalent. The first two issues after the beginning of the war are the best examples to the Iraqi regime's attempts to convince people, including children, of war as a fair case.

Majalaty provided children with various kinds of stories that depicted war in a strikingly realistic

way where violence was praised in every line. Characters, plot, setting, and illustration served as the media to glorify war. The amount of violence found in the magazine's war issues shaped the personality of thousands of children for years. The magazine focused on two significant factors: first, militarizing its content from the cover to the last page, by presenting death as a noble goal and killing the enemy is a synonym of heroism, secondly, normalizing war by presenting it as inseparable from people's everyday life. It is important to mention that in the first years of war the number of war stories was higher than in later years.

The $22^{\text {nd }}$ of September 1980 issue's cover page illustrates a soldier smiling and looking far, while two frowning children sitting on his shoulders. A big sun painted in the background with the slogan 'victory is ours' on the right side. Happiness is usually related to childhood. When the illustrator chooses to illustrate the children frowning instead of smiling, it sends a message to children, telling them to be prepared for this war. Facial expressions show anger that is supposed to be directed towards the enemy. In this way, young readers will understand that all sections of society of all ages are engaged and ready to fight in this conflict. It is not adults' war only, but children's too. The slogan shows a contradiction with the illustration since victory is supposed to make people happy, not angry.

The first story in this issue is Abdulilah Rauf's Little Juha. The stories of Juha exist in every issue, however, in this issue; it changed its topics to be more pro-war and adopted militaristic language. Juha is presented wearing a military uniform and telling the readers about his soldier brother. The first sentence is "My elder brother arrived at night, wearing his military uniform and carrying his machine gun" (Rauf 1980, p.1; my transaltion). This sentence initiates years of glorifying war stories in Iraqi children's literature.

The Little Fighter, written by Saeed Farhan, is another story, featuring an angry boy with challenging facial expressions (Farhan1980, p.2; my trnaslation). He presents himself as 'Asaad' (lion) whose father is a soldier, raining the enemies with bullets. He tells the readers that he has decided to join his father on the battlefield by volunteering in the People's Army. When he is rejected because of his young age, he insists that he is old enough to attack a tank. Then, he is advised to help his friends in the traffic. The story ends with him standing in the street cheering the soldiers who are back from the battlefield. The desire to act like adults is encouraged in this story. Instead of living their age, children are presented as being anxious to be older in order to fight the country's enemy. This desire is praised and rewarded at the end of the story. This story also celebrates the idea of joining the People's Army. Founded in 1970, this army was meant to give the Baath Party an active role in the towns and villages. However, during the 1980s, it undertook a new task by supporting the regular army at war. During the early years of war, its most significant role was to secure buildings in the cities, with the constant absence of the regular army. By 1987 Iraq's total armed forces reached over a million and a half, in which the People's army numbered 650,000. The backup that this army presented made it essential for the government to encourage ordinary people to join in (Boo et al., 2020).

Grandpa Tales, written by Abdulilah Rauf, is a popular story that usually presents social themes (Rauf 2020; my translation). The narrator is 'Grandpa' who is recognized of his white beard and a kind smile. The tales have a long history in Majalaty, since they are found in most of the issues. However, since the beginning of the war, its main focus was glorifying war. In September 1980s issue, the tale presents war as the main theme by using historical figures. Grandpa informs the readers that he told his grandchildren about Saad bin Abi Waqas, a notable Muslim leader who is known for his commandership in the Battle of Al-Qadisiyyah and in the conquest of Persia in 636. Here, there is a comparison between Saad and Saddam Hussein as famous leaders who led wars against the Persians. Iran-Iraq war was later called ' Qadisyat Saddam'. The writer is deriving parallels between both wars to achieve the same victory. Grandpa tells his grandchildren.

Yes. The Arabic Iraq led by 'Saddam Hussein' has won against the assaulted Persians. We proudly have the right to call our battle 'Qadisiya Saddam', 
since it rejuvenated the glories of Al-Qadisiyyah... Let this victory and all the efforts that made it be blessed (Rauf 1980; my translation)

The narrator here affirms that Iraq is going to win the war by simply relating it to another war that was hundreds of years ago. The parallel was drawn based on weak similarities, like the Arabic leader who is fighting against the Persians. Another key point is the constant attempts to present it as a war between the Arabs and the Persians, not between Iraqis and Iranians. This fuels the sectarian spirit and hides the fundamental reasons for the conflict. It even misleads young readers by deceiving them that the first war based on similar reasons. Saad Bin Abi Waqqas did not represent Arabs but Muslims. The Muslims at the time belonged to different ethnic groups. During Iran- Iraq war, all Iraqis were forced to fight, regardless of their religion, ethnicity, or race. It is important to mention that Iraq is a multi-ethnoreligious country. Eventually, all citizens were victims of this war. This story is an example of the attempts to historicize the texts by including historical figures and reflecting present values.

The second issue of Majalty which published on the $13^{\text {th }}$ of October 1980, after the beginning of war intensified the war themes and was more direct in relating it to the President Saddam Hussein. The cover page features his picture smiling gently and being carried by many children as if walking in a demonstration. The Iraqi and Palestinian flags are seen in the background with a 'Long live the president-long live the army-long live the nation' sign. The first story in this issue is For the Sake of the Leader (2020; my translation). It starts with Little Juha on the roof of his house, eagerly watching the enemy's fighting planes smashed by the Iraqi's mortar bombs. He disobeys his father and stays out. The father tells Juha that he puts the life of an Iraqi citizen in danger which means that he disobeys the president who advised all the Iraqis not to do so. Little Juha finally agrees not out of fear, but for the sake of the president and all Iraqis. The story shows the fearless hero who enjoys watching 'the enemy's airplanes being bombed and torn into pieces' (Rauf 1980, p.1). It instructs children not only to be violent but also to celebrate violence. Although it is mentioned that people should not be in danger, violence was constantly encouraged. Plus, relating this to the president is nothing but an implied lesson to teach the children to be obedient to one person; Saddam Hussein. The safety of people was the last thing the Iraqi regime thought of at that time. People were in danger for years and claiming the opposite was a mere lie.

Another story in the same issue is Sharif Alrass's What Wadhah Said in His Notebook of Happiness (Al-Rass 2020; my translation). Wadhah is the main character who wants to write a book about the victory of the Iraqis in war. He decides to collect the pictures that express the happiness of victory. The first picture shows a girl and a boy with Palestine's flag behind them. The story intentionally relates the war to the case of Palestine quoting from the president 'Hold the flag of our great ancestors high... The sun said to us you are free Arabs who deserve the greatest victory' (Al-Rass 1980, p.3; my translation). Another picture shows an Arabic old man from Al-Mohamara. It is mentioned that Al-Mohamara is an Arabic city that was abducted for sixty years until Saddam Hussein returned it back from the Persians. The picture of Saad bin Abi Waqqas is also included since he is the leader who won Al-Qadisya battle against the Persians 1400 years ago. Wadhah asks the readers "Don't you think that Qadisyat Saddam reminds us of Qadisyat Saad bin Abi Waqqas in which we defeated the Persians?" (Al-Rass 1980, p.5; my translation). This story presents a considerable number of ideas First, the case of Palestine has been used constantly whenever Iraq is at war. There was an attempt to portray this image in which Iraq fights on behalf of all Arab countries, giving the conflict a nationalistic orientation. Secondly, the Iraqi regime at that time worked systematically to convince people that the Iraqis were fighting for the sake of Saddam Hussein, not Iraq. He is the president and the father of all Iraqis. Thirdly, in order to justify the war, the regime used many Muslim leaders who fought against the Persians like Saad bin Abi Waqqas as an attempt to historicize the war. Finally, it claims that Iraqis have already won the war, while the fact is, they needed to wait for eight years to end it.

Children's Culture House, the main governmental publisher in Iraq, published a series of stories and poems about the war during the 1980s. Among the most famous collections of stories is Asad Albar, written by Abdul Ilah Rauf. The book includes seven short stories about Iran-Iraq war. The Pole Star tells the story of two lost soldiers who find themselves behind the enemy border (Rauf 2020; my translation). They decide to go south with the help of the pole star when suddenly find Iranian soldiers. The Iraqis succeed in ambushing and catching them all. Ironically, the story shows the Iranian as naïve and easily deceived. They are described as 'the racist Persians' who immediately surrender without any resistance. Taking them as war prisoners is a victory. Stories about war prisoners try to hide the inhumane treatment these hostages get.

Saady The Sailor, another story witten by abdulilah Rauf, represents the concept of self-sacrifice which was highly celebrated at that time. Saady saves other sailors when his boat is bombed and 'the sea hugs the remains of his body lovingly' (Rauf 1981, p.22; my translation). The story encourages children to follow this great soldier who is considered to be a role model in defending his land and protecting the lives of others. 
This contributes to the idea of the honorable death that every citizen should seek. However, violent expressions are used explicitly like 'his body is scattered into pieces' (ibid).

The fourth tale is about 'Kheiry', the brave soldier who spends more than ten hours fighting without showing any signs of tiresome. Finally, he is attacked by a sniper, but another soldier saves him by taking the bullet instead. Kheiry, when he sees what happened, shouts loudly and hugs the body of his friend. His shouts mix with other soldiers' shouts, cheering president Saddam Hussein. They are celebrating winning back Al-Mohamara city from the Persians (Rauf 1981, p.23). Using this implicit discourse is highly ideological. Representing these men as the soldiers of the president is a way to personalize the conflict. The whole country was represented by one man. Therefore, it misrepresents the struggle since the soldiers fight for Saddam Hussein, not for the sake of defending their country.

Abulilah Rauf 's Asad Albar is the longest story in this book. Here, the battle takes place near 'Bahmashir' river. The writer intentionally includes real settings. Sabah, the protagonist, is a member of the special forces team that is located there to defend the area. He exhibits great courage when he decides to cross the river swimming to surprise the enemy. He remembers his determination to join the army when he was young which motivates him to attack the enemy soldiers. When other members of the team come and find Sabah hugging his machine gun strongly, they decide to bury them together. This is a sign of Sabah's loyalty to his country. It is mentioned that the enemy left the injured and the dead soldiers then fled the area. Showing the Iranian soldiers as cowards enforces the image of the valiant Iraqi soldiers (1981, p.25).

A Mission in The Darkness is a book from the series of Qadisyat Saddam which includes seven short stories (Hussein1984; my translation). It is written by Jabbar Hussein and illustrated by Dhyaa Alhajar. It is worth mentioning that the name of the writer as mentioned in the book is a mere pen name while the real name is Abuljabbar Nasser. As the writer explains, he was taken as a war prisoner in Iran in the beginning of the war. Therefore, he was given a pen name to hide his identity. If the Iranian government knew about the stories of war he had written, he would be in real danger. The book was published during the time he was in prison ( $\mathrm{T}$. Kheirbek 2020, personal communication, 29 December).

The Observatory, written by Jabbar Hussein, is one of the stories in which Zeidan (the protagonist) and the other soldiers climb the mountain in West Kailan to face the enemy (Hussein 1984; my translation). He shows great bravery as a snipper to take over an observatory. Zeidan gets promotion which makes him very happy. In the story, it is mentioned that the president grants Zeidan the first promotion for attacking an Iranian military airplane. The second one is for targeting enemy soldiers and take over their place. One of the illustrations shows Zeidan shooting and killing three Iranian soldiers. The illustrations or pictures in the story show the implicit messages the text tries to convey. Iranian soldiers are featured as frightened bearded men who are trying to run away while Iraqi soldiers are illustrated as young handsome men with shaved beards and elegant military uniforms. The image of an Iraqi soldier heading his rifle towards an Iranian soldier and with the bullet penetrating his body not only seems to encourage violence but celebrates it.

Another story in this book is The Three Officers (Hussein1984; my translation). The setting is in AlMohammara or Khormshaher, the famous Ahwazian city. Three officers succeed in resisting the attack of twenty Iranian soldiers using three hand grenades. They are able to kill some and take the rest as war prisoners. The battle in Al-Mohammara is considered one of the fiercest in Iran-Iraq war. It was important for the Iraqi regime to prove that they were moving forward. This story was written when the Iraqis were struggling to capture the city. It witnessed ferocious battles, ending with the Iranians recapturing it in May 1982. The description of the incidents is so realistic that it takes the readers immediately to the battlefield. The illustrations show two Iranian soldiers bombed with the hand grenades and the others taken as war prisoners by the victorious Iraqi soldiers. Despite the Iranians' military superiority in the story, the Iraqi soldiers miraculously succeed in saving themselves and defeat the Iranians.

A Suitable Rifle for Little Waleed! written by Abdulrazaq Al-Mutaliby) shows how parents are expected to encourage their children to be in the military (Translated by me 1986). Waleed sees his father searching for his weapon, which he hid earlier in an old box. His father discovers what Waleed did and smiles. He is proud of his son who hid the rifle to use it in the future when he becomes a soldier like his father. The father leaves his rifle with his son and his wife and goes out fast. When he returns, he brings a fake machine gun. He feels very happy and thanks his father for this precious gift. His father promises him that he is going to have his real rifle when he is older (Al-Mutaliby 1986, pp. 6-7). Children tend to identify with characters in the stories. Seeing Waleed happy with his new weapon encourages them to do the same. Carrying and using weapons is presented as an act of bravery and heroism which negatively influence their understanding of these concepts.

According to Andrea Wyile's categorization, the stories written and published during Iran-Iraq war show 
the first and the second types immediate-engaging firstperson narration and immediate-engaging third-person narration (1999, p.195). The time of the narration is in coincidence with the events happening at that time. Therefore, young readers are attracted to the subjects since it reflects the public mood. In addition to that, the stories are heavily character focalized.

Ideological messages can be easily detected in the stories written for children during the 1980s. Being loyal to the governing regime is a priority. Therefore, propagandists focus on presenting texts that encourage children to demonstrate their love to their country by blindly following the governing regime. The stories are full of military terminology and militaristic pictures which invade the pages of children's books and feature the battles realistically. A comprehensive description of army units, weaponry, and equipment are usually provided, and the beautiful military uniform is always praised. The stories mainly give an image of the Iraqi martial ideology. Lessons in duty and service are implied in these stories to indicate that the army consists of citizen-soldiers. The men who serve in the army have been selected from all walks of life which signify that the army represents a nation, and the nation represents an army. These lessons exist in almost all the literature written at that time, encouraging young readers to commit to the duties laid upon them by sharing in the tasks, and self-sacrificing when they become adults.

The Propagandistic discourse highly exists in these texts. Proclaiming the Iraqi army's superiority is one of the essential characteristics of these texts. These stories tend to present a unique sympathetic relationship between young readers and the army. They additionally include a positive image of military life. The aim is to encourage children to identify with the soldiers fighting in endless battles and consequently prepare them to be part of the military body in the future. They also nourish children's minds with politicized and militarized themes, plots, and characters.

\section{CONCLUSIONS}

During the 1980s, writers presented war as an appealing adventure and a noble cause in which all people should participate. The implicit slogan that they convey is to kill or to be killed. Through depicting battlefields realistically young readers are provided an early entry into the adult world. This distracted children from the violence and destruction war brought to their lives. Consequently, the war was normalized. In these powerful and many-layered texts and illustrations, the hidden messages exist to encourage children to be copies of thousands of soldiers who joined a war that was nothing but a pit of death.

Iraqi children's literature was politicized and militarized during the 1980s. It worked on conveying ideological messages that celebrated the positive side of the governing system and their choice of war, as well as magnifying the negative image of the enemy. It was significant to plant the seed of allegiance to the state in the young souls while presenting war as a natural reaction to any threats. Peace was hardly presented as an option. The whole nation is in a state of war, rearguard is hand in hand with the vanguard. Children and adults are part of this war. Young readers should have been reminded that war destroys not only nations but also kills childhood's innocence instead of flooding the libraries with jingoistic texts.

\section{REFERENCES}

Al-Mutaliby, A. (1986), “A Suitable Rifle for Little Waleed!”, Majalaty ,vol.16, no.38,pp. 6-7.

Al-Rass, S. (1980), "What Wadhah Said in His Notebook of Happiness", Majalaty , vol. 11, no.42, pp. 3-5.

Ardizzone, E. (1980), "Creation of a Picture Book", Only Connect. Readings on Children's Literature, Egoff, S. et al. Eds., Oxford University Press, Toronto.

Augesten, A. et al. (2020), "Iran-Iraq War", https://www.britannica.com/event/Iran-Iraq-War [Accessed 20 Sep. 2020]

Boo, F. et al. (2020), "The People's Army", https://www.globalsecurity.org/military/world/iraq/militia.h tm [Accessed 20 Nov. 2020]

Dixon, B. (1977), "Catching Them Young, Sex, Race and Class in Children's Literature", Pluto Press, London.

Farhan, S. (1980), "The Little Fighter", Majalaty, vol. 11, no. 40.

Fox, C. and Hunt, P. (2004),"War", International Companion Encyclopedia of Children's Literature, vol. 1, Routledge, New York.

Giblin, J. (1995), "Violence, Children, and children's books", School Library Journal, vol. 41, no. 11, pp.30-31.

Goodenough, E. (2000)," Children's Literature and Violence: Introduction", The Lion \& the Unicorn, vol. 24, no.3, pp. v-ix.

Harrison, B. (1987), "Howl Like the Wolves", Children's Literature, vol. 15 , pp. $67-90$.

Hussein, J. (1984), “A Mission in The Darkness”, Children's culture House, Baghdad.

Mccllum, R. and Stephens, J. (2010), “Ideology in Children's books”, In book: Handbook of Research on Children's and Young Adult Literature, Shelby, W. Ed., Routledge.

Rauf, A (1980), “Grandpa's Tales”, Majalaty, vol. 11, no. 40.

Rauf, A. (1981), " Asad Albar", Children's Culture House, Baghdad.

Rose, J. (1984), "The Case of Peter Pan or the Impossibility of Children's Fiction", Macmillan, London.

Rudman, M. (1995), “Children's Literature”, Longman Publishers, New York.

Salwi, D. (1998), "Peace Through Science Fiction?", The 26th Congres s of the International Board on Books for Young People.

Stephens, J. (1992), “Language and Ideology in Children's Fiction”, Longman, London.

Wyile, A. (1999),"Expanding the View of First-Person Narration", Children's Literature in Education, vol. 30,pp.185-202. 